\title{
Toxicity of ammonia to turbot juveniles: 1. effects on survival, growth and food utilisation
}

\author{
A Jeannine Person-Le Ruyet*, Christine Delbard, Hervé Chartois and Hervé Le Delliou
}

IFREMFR, Laboratoire de Recherches aquacoles, BP 70, 29280 Plonzané, France. E-mail:jperson@ifremer.jr

Received June 6, 1997; accepted September 17, 1997.

Person-Le Ruyet J., C. Delbard, H. Chartois, H. Le Delliou. Aquat. Living Resour., 1997, 10, 307-314.

Abstract

Long-term effects of constant exogenous ammonia concentrations were investigated in two different batches of turbot juveniles (53 and $73 \mathrm{~g}$ ) under controlled environmental and feeding conditions. Over the 84-day expcriments, ambient un-ionized ammonia (UIA- $\mathrm{N}, \mathrm{NH}_{3}$ ) concentrations were steady (coefficient of variation, $12-16 \%$ ) and water $\mathrm{pH}$ range was 7.88-7.99. Survival was maximum up to $0.33 \mathrm{mg} . \mathrm{l}^{-1}$ UIA-N and at $0.73,50 \%$ mortalities were observed on day $52(73 \mathrm{~g})$ or day $77(53 \mathrm{~g})$. No-growth concentration was $0.73 \mathrm{mg} .1^{1}$ UIA-N in the two groups and the 84-day lowest-observable-effect concentration range 0.14-0.33 $\mathrm{mg} . \mathrm{I}^{-1}$. In the most tolerant group $(53 \mathrm{~g})$, the 84 -day no-observable-effect concentration was $0.14 \mathrm{mg} . \mathrm{l}^{-1}$ UIA-N. The estimated 28-day efficient concentration that gave $50 \%$ of the specific growth rate of controls ranged from 0.60 to $0.75 \mathrm{mg} .1^{-1}$ UIA-N. Specific growth rate to ambient ammonia concentration patterns were different in the two groups for the lowest concentrations (0.14-0.34) and similar to food intake to ammonia pattern. Food efficiency was negatively correlated to ambient ammonia concentration, with major changes in food conversion ratio, and protein utilisation observed above $0.33-0.70 \mathrm{mg} . .^{-1}$ UIA-N. The main change in body composition was an increase in water content in all ammonia-exposed fish. A significant increase in urea-N excretion rate was also observed over $0.33 \mathrm{mg} . \mathrm{I}^{-1}$ UIA-N. Thresholds for growth were affected by exposure duration. Turbot juveniles growth capacity may be depressed by usual ambient ammonia concentrations under intensive farming conditions.

Keywords: Ammonia, chronic toxicity, survival rate, growth, food efficiency, Psetta maxima.

Toxicité de l'azote ammoniacal chez le turbot juvénile : l. effets sur la survie, la croissance et l'alimentation.

Résumé

Les effets à long terme de concentrations constantes en azote ammoniacal ont été étudiés chez deux lots différents de turbot ( 53 et $73 \mathrm{~g}$ ) en conditions contrôlées (environnement et alimentation). Au cours des 84 jours d'expérience, les concentrations en $\mathrm{NH}_{3}$ ont été stables (coefficient de variation, 12-16\%) ainsi que le $\mathrm{pH}$ ambient (7.88-7.99). La survie a été maximale jusqu'à $0.33 \mathrm{mg}^{-1} \mathrm{I}^{-1} \mathrm{NH}_{3}$ et à 0.73 , des taux de mortalité de $50 \%$ ont été observés au jour $52-77$ selon le lot. La croissance a été arrêtée à $0.73 \mathrm{mg} . \mathrm{l}^{-1} \mathrm{NH}_{3}$ et significativement affectée à partir de $0.14-0.33 \mathrm{mg} . \mathrm{l}^{-1} \mathrm{NH}_{3}$. Chez le lot le plus tolérant $(53 \mathrm{~g})$, la concentration n' induisant pas d'effet sur la croissance pour une durée d'exposition de 84 jours a été de $0.14 \mathrm{mg} . \mathrm{l}^{-1}$ UIA-N. Au jour 28 , le taux de croissance spécifique a été réduit de $50 \%$ à $0.60-0.75 \mathrm{mg} . \mathrm{l}^{-1} \mathrm{NH}_{3}$. Les variations du taux de croissance spécifique et du taux d'alimentation en fonction de la concentration en $\mathrm{NH}_{3}$ ont eu le même profil avec quelques différences observées entre les 2 lots. L'exposition prolongée à des concentrations en $\mathrm{NH}_{3}$ excédant $0.33-0.70 \mathrm{mg} . \mathrm{I}^{-1}$ a entraîné une baisse des performances alimentaires. Les modifications majeures de la composition corporelle des poissons ont été une augmentation de la teneur en eau pour toutes les concentrations. Une augmentation du taux journalier d'excrétion uréique a été aussi observée au-delà de $0.33 \mathrm{mg} . \mathrm{l}^{-1}$. Les seuils de tolérance sont dépendants de la durée d'exposition. Les seuils de perturbation de la croissance du turbot juvénile correspondent aux concentrations rencontrées en conditions d'élevage intensif.

Mots-clés: Azote ammoniacal, toxicité chronique, taux de survie, croissance, alimentation. 


\section{INTRODUCTION}

Ammonia is the main form of nitrogenous waste in teleosts and in intensive fish farming it may become a limiting factor for growth and even survival. Considerable information on the sensitivity of freshwater species to ammonia under difrerent environmental conditions has already been reported (Russo and Thurston, 1991; Wood, 1993; Tomasso, 1994 reviews). In comparison, available knowledge of short-term and long-term responses of marine fish species to ammonia is still limited (Handy and Poxton, 1993; Wajsbrot et al., 1993; Person-Le Ruyet et al., 1997). The scarcity of data concerning chronic ammonia toxicity may be partly explained by technical difficulties encountered in studying direct effects of ammonia even at a laboratory scale. As seabass (Dicentrarchus labrax), seabream (Sparus aurata) and turbot (Psetta maxima, or Scophthalmus maximus. ${ }^{1}$ ) farming is developing well in Europe, reliable data for ammonia toxicity are required for defining environmental quality standards and security monitoring systems especially in intensive culture systems.

Un-ionized ammonia (UIA-N) is the most toxic form of total ammonia nitrogen (TAN). This term refers to the sum of UIA-N $\left(\mathrm{NH}_{3}-\mathrm{N}\right)$ and ammonium ions $\left(\mathrm{NH}_{4}+\right.$ ). In marine fish farming (using high $\mathrm{pH}$ and temperature), the ratio of UIA-N to TAN is high (2-4\%) in comparison with freshwater fish culture. In terms of survival, juveniles of seabass, seabream and turbot are tolerant to short-term ammonia exposure: 96-h LC50 (lethal concentration for $50 \%$ of the population) are 1.3-2.6 mg..$^{-1}$ UIA-N (Wajsbrot et al., 1991; Person-Le Ruyet et al., 1995). When exposed to ammonia, moderate or severe physiological disturbances, depending on the level of ammonia and exposure duration, are immediatcly observed (Person-Le Ruyet et al., in press). From this, we can assume that growth may be impaired at low ambient ammonia concentrations by long-term exposure. Available data showed that in turbot and seabream juveniles exposed to constant ammonia concentrations for one-month maximum, the range of chronic toxicity thresholds for growth is 0.1-0.4 mg. $\mathrm{I}^{-1}$ UIA-N (Alderson, 1979; Wajsbrot et al., 1993; Rasmussen and Korsgaard, 1996; Person-Le Ruyet et al., 1997).

The purpose of this study was to investigate longterm responses of turbot juveniles maintained under constant UIA-N concentrations and controlled environmental conditions for 3 months (chronic ammonia toxicity). This exposure duration is over the minimum of one month recommended for toxicity tests on fish growth (Kooijman et al., 1996). Effects of ammonia on survival, growth and food utilisation efficiency are presented. Chronic toxicity thresholds changes with exposure duration are discussed.

\footnotetext{
${ }^{1}$ Psetta maxima (Linnacus, 1758) preferably to Scophthalmus maximus (Rafinesque, 1810).
}

\section{MATERIAL AND METHODS}

\section{Fishes and tests conditions}

The experiments were carried out with 2 different class-size: $\mathrm{A}, 73.4 \pm 1.4 \mathrm{~g}$ and $\mathrm{B}, 53.2 \pm 1.4 \mathrm{~g}$ (mean \pm s.c) of hatchery-reared turbot from the same parental stock (Atlantic strain) which were used 10 months after hatching. They were performed in $1 \mathrm{~m}^{2}$ Swedishtype tanks, with an effective water volume of 3501 , supplicd with running sea water of $34.9 \pm 0.1$ salinity (mean \pm s.e). Temperature which was checked daily was in the optimal range for turbot juveniles growth, $17.31 \pm 0.05^{\circ} \mathrm{C}$ (Burel et al., 1996). Water exchange rate was $100 \%$ per hour and oxygen levels (pre-feeding levels) averaged $5.6 \mathrm{mg} . \mathrm{l}^{-1}$ in controls and 6.3 for the highest concentrations tested (Table 1). The $\mathrm{pH}$ of water in each tank was checked each time the TAN concentration was measured using an Orion $901^{(B)} \mathrm{pH}$ meter filted with a Fermprobe ${ }^{(B)}$ electrode (accuracy 0.01 ). Photoperiod was maintained on a $18 \mathrm{~h} \mathrm{~L}: 6 \mathrm{~h} \mathrm{D}$ cycle and light intensity was 2 W.cm ${ }^{-2}$ at the water's surface.

One month before experimentation, the 2 groups of fish ( $A$ and $B$ ) were maintained in two $4 \mathrm{~m}^{2}$ tanks and acclimated to the preselected experimental temperature and food. They were then randomly distributed between the experimental tanks $\left(1 \mathrm{~m}^{2}\right)$ and allowed to adapt for 3 weeks. Initial fish number was 113 in group $A$ and 93 in group B (initial stocking density of 23 and $14 \mathrm{~kg} \cdot \mathrm{m}^{-3}$ respectively). They were hand-fed twice a day to satiety on a home-made extruded pellet (total protein and crude fat: $60.9 \%$ and 13.9 of dry matter respectively) used as reference at Ifremer to ensure the nutritional requirement of turbot juveniles (Guillaume et al., 1991). On the day of sampling they were only fed once.

In each tank, a concentrated solution of $\mathrm{NH}_{4} \mathrm{Cl}$ (20$125 \mathrm{~g} \mathrm{NH}_{4} \mathrm{Cl}_{1} \mathrm{I}^{-1}$ fresh water) was added to the water inflow by a peristaltic pump. Ambient TAN (pre-feeding level of each tank) was measured once a day the first week and every 3 days afterwards when the $\mathrm{NH}_{4} \mathrm{Cl}$ solution was renewed. When necessary (minor changes in ambient $\mathrm{pH}$ and salinity), the concentrated $\mathrm{NH}_{4} \mathrm{Cl}$ solutions was adjusted to stabilize UIA-N concentrations.

\section{Experimental design and analytical procedures}

Five constant UIA-N concentrations, plus a control (no-ammonia added), were tested in the two groups of fish, A and B (Table 1). They ranged from usual concentrations observed in intensive fish farming (Handy and Poxton 1993) and chronic toxicity thresholds previously determined in turbot juveniles exposed to ammonia for 4 to 6 weeks (Person-Le Ruyet et al., 1997). Fish were fed to saticty and the food intake by the fish of each tank was recorded daily.

The experiment lasted 12 weeks (March-June). Group B was exclusively used for growth data while in group A, 10 fish were regularly sampled (day $7,14,28$, 
Table 1. - Ambient un-ionized ammonia (UIA-N, mg..$^{-1}$ ), total ammonia nitrogen (TAN, mg..$^{-1}$ ), pH, oxygen (mg..$^{-1}$ ) conditions used in the two groups of turbot, plus stocking density $\left(\mathrm{kg}, \mathrm{m}^{-2}\right)$ at day 0,56 and 84 . $\mathrm{C} 4$ and $\mathrm{C} 5$ terminated after 56 days due to mortality. Means are given with standard crrors and $\mathrm{n}$ (in brackets).

\begin{tabular}{|c|c|c|c|c|c|c|c|c|c|c|c|}
\hline \multicolumn{2}{|c|}{ Group } & \multicolumn{2}{|c|}{ UIA-N } & TAN & \multicolumn{2}{|c|}{$\mathrm{pH}$} & \multicolumn{2}{|c|}{$0_{2}$} & \multicolumn{3}{|c|}{ stocking density } \\
\hline \multirow{4}{*}{ A } & $\mathrm{CO}$ & $0.004 \pm 0.00044$ & $(30)$ & $0.16 \pm 0.01$ & $7.96 \pm 0.01$ & (28) & $5.64 \pm 0.14$ & $(12)$ & 7.93 & 7.48 & 7.47 \\
\hline & $\mathrm{C} 2$ & $0.34 \pm 0.01$ & (29) & $11.42 \pm 0.34$ & $7.93 \pm 0.01$ & (28) & $5.95 \pm 0.16$ & (12) & 8.29 & 6.67 & 6.31 \\
\hline & $\mathrm{C} 3$ & $0.73 \pm 0.22$ & (28) & $21.15 \pm 0.46$ & $7.97 \pm 0.02$ & (25) & $6.01 \pm 0.14$ & (10) & 8.51 & 0.9 & \\
\hline & $\mathrm{C} 4$ & $1.11 \pm 0.04$ & (17) & $34.39 \pm 1.24$ & $7.91 \pm 0.01$ & (15) & $6.23 \pm 0.14$ & (7) & 7.97 & & \\
\hline \multirow{5}{*}{ B } & $\mathrm{Cl}$ & $0.14 \pm 0.005$ & (30) & $5.15 \pm 0.15$ & $7.98 \pm 0.01$ & (28) & $5.94 \pm 0.13$ & (11) & 4.83 & 8.33 & 9.84 \\
\hline & $\mathrm{C} 2$ & $0.33 \pm 0.0]$ & (27) & $11.63 \pm 0.42$ & $7.94 \pm 0.01$ & (28) & $5.64 \pm 0.11$ & (I1) & 4.45 & 7.21 & 8.31 \\
\hline & $\mathrm{C} 3$ & $0.71 \pm 0.02$ & $(29)$ & $20.0 \pm 0.5$ & $7.99 \pm 0.02$ & (28) & $6.28 \pm 0.13$ & (12) & 4.76 & 4.19 & \\
\hline & $\mathrm{C} 4$ & $1.17 \pm 0.04$ & (20) & $32.49 \pm 0.95$ & $7.97 \pm 0.01$ & (19) & $6.46 \pm 0.12$ & (9) & 4.43 & & \\
\hline & $\mathrm{C} 5$ & $1.20 \pm 0.05$ & (17) & $41.19 \pm 1.29$ & $7.92 \pm 0.01$ & (15) & $6.33 \pm 0.11$ & (8) & 4.79 & & \\
\hline
\end{tabular}

54,66 and 84 ) for blood analysis (blood samples taken within one minute from caudal vessels in fish killed by anesthesia; physiological data not presented in this paper). As a result, stocking density in the controls was constant in group A while a 2-fold increase from the onset to the end of the experiment was observed in group B (Table 1).

Water TAN analysis was determined with a precision of $0.003 \mathrm{mg} . \mathrm{l}^{-1}$ by an automatic colorimetric method (modified indophenol blue method) described by Dosdat et al. (1994). UIA-N concentrations were calculated using the equation of Johnson and Wedborg (1980) which gives the ratio of UIA-N to TAN as a function of $\mathrm{pH}$, temperature $\left(\mathrm{T}=\mathrm{t}^{\circ} \mathrm{C}+273.15\right)$ and salinity:

$$
\mathrm{NH}_{3}+\mathrm{H}^{+} \Leftrightarrow N H_{4}^{+} \text {with } K_{1}=\frac{\left[N H_{4}^{+}\right]}{\left[N H_{3}\right]\left[H^{+}\right]}
$$

$\log K_{1}=-0.467+0.00113 \times S+2887.9 \times T$

Results are expressed in mg. $1^{-1}$ UIA-N ( 1 mg. $\mathrm{l}^{-1}$ equivalent to $\left.0.017 \mathrm{mmol.} \mathrm{I}^{-1}\right)$, the equivalent TAN are reported in Table 1.

\section{Studied parameters}

Mortalities were daily counted to determine LC50s (the UIA-N concentrations which produced $50 \%$ mortality of the population) for different exposure durations. Every two weeks, 35 turbot from each tank were weighed individually to $0.1 \mathrm{mg}$ (no-anesthesia used) and specific growth rate (SGR) was calculated using the following expression: $100\left(\ln w_{f}-\ln w_{i}\right)$.days ${ }^{-1}$ where $w_{j}$ and $w_{f}$ are respectively the initial and final mean body weight.

Different food utilisation parameters were also calculated using the following expressions where food intake, protein intake and protein gain were expressed as dry weight and fish biomass as wet weight:

- food conversion ratio (FC): total food intake $x$ total fish biomass gain ${ }^{-1}$, -daily food intake (FI): 100 (amount of food ingested per day $\times$ average total fish biomass ${ }^{-1}$ ),

- protein efficiency ratio (PER): total biomass gain $\times$ protein intake ${ }^{-1}$,

- protein utilisation coefficient (PUC): 100 (fish protein gain $\times$ protcin intake ${ }^{-1}$ ).

Proximal analyses of food and fish body composition were performed using classical methods (AOAC 1984): dry matter $\left(24 \mathrm{~h}\right.$ at $\left.105^{\circ} \mathrm{C}\right)$, ash $\left(7 \mathrm{~h}\right.$ at $\left.550^{\circ} \mathrm{C}\right)$, crude lipid (dichloromethane extraction with an Automatic Soxtec System $\mathrm{Ht}^{(1)}$ from Perstorp Analytical) and crude protein (Dumas method with an Elementary NA $2000^{(1)}$ from Thermo Separation Products, $\mathrm{N} \times 6.25$ ). Body composition was determined in triplicate using freeze-dried samples from three sets of 20 fish each taken from the initial population (that is 9 analyses in total) and of 10 fish from each experimental condition at the end of the experiment.

At the end of the growth experiment (day 77), average daily urea- $\mathrm{N}$ excretion rates were calculated from urea- $\mathrm{N}$ contents of pooled samples of water in turbot fed to $80 \%$ of satiation (total excretion) and from day 101 in 7-day starved turbot (endogenous excretion). Water samples were semi-continuously collected for $24 \mathrm{~h}$ and 5 consecutive days in 11 flask with preservative $\left(10 \mathrm{ml} . \mathrm{l}^{-1}\right.$ chloroform) from the outflow of each experimental tank through a peristaltic pump plus in water inflow of controls. They were frozen at $-16^{\circ} \mathrm{C}$ pending essays. Urea- $\mathrm{N}$ was analyzed by the acetylmonoxyme method and the excretion rate calculated from biomass and flow rate as described by Dosdat et al., 1994. Results are expressed in mg urea-N. $\mathrm{kg}^{-1}$ wet w.day ${ }^{-1}\left(\mu \mathrm{mol} . \mathrm{l}^{-1}\right.$ urea-N equivalent to $28 \mathrm{mg} . \mathrm{l}^{-\mathrm{P}}$ ).

\section{Data analysis}

All results are expressed as mean values with the standard error of the mean. Data were checked for normality of variance and log-transformed when necessary before being analysed statistically. At each sampling date, the influence of ambient UIA-N con- 
Table 2. - Survival, growth and food utilisation data (as specified in Materials and Methods) as a function of ambient UIA-N in group A (73 g) and B (53 g), plus. in group B, total urea-N excreted to ambient UIA-N in 24-h-fasted turbot and endogenous urea-N excreted in 5-day-starved turbot.

Data are means with standard errors: weight data, $n=35$ per tank and per sampling date and urea- $N$ excretion data, $n=5$. Superscript letters indicate intergroup statistical differences between ambient UIA-N concentrations (one-way ANOVA and Tukey multirange analysis using individual wcight or log (weight). Means not sharing a common letter are significantly different $(p<0.05$ ).

\begin{tabular}{|c|c|c|c|c|c|c|c|c|}
\hline Group & & $\mathrm{C}(3$ & & $\mathrm{Cl}$ & & $\mathrm{C} 2$ & & C3 \\
\hline \multirow{6}{*}{ A } & Initial weight (g) & $73.4 \pm 1.4$ & & $71.1 \pm 1.3$ & & $73.4 \pm 1.8$ & $b$ & $73.4 \pm 2.2$ \\
\hline & Final weight $(g)$ & $196.6 \pm 8.5$ & $\mathrm{c}$ & $158.3 \pm 6.9$ & $b$ & $146.7 \pm 7.8$ & & $*(75.5 \pm 2.2)$ \\
\hline & Final survival (\%) & 100 & & 100 & & 100 & & 0 \\
\hline & Daily food intake ( $\%$ ) & 1.6 & & 1.4 & & 1.3 & & 0.97 \\
\hline & Protein efficiency ratio & 30.5 & & 25.9 & & 22.7 & & 3.2 \\
\hline & Protein utilisation coefficient & 2.0 & & 1.8 & & 1.6 & & 0.8 \\
\hline \multirow{6}{*}{ B } & Final survival (\%) & 100 & & 100 & & 100 & & 46 \\
\hline & Food conversion & 0.60 & & 0.75 & & 0.8 & & 1.75 \\
\hline & Daily food intake (\%) & 1.2 & & 1.1 & & 1.1 & & 1.0 \\
\hline & Protein efficiency ratio & 34.8 & & 28.4 & & 25.3 & & 4.0 \\
\hline & Protein utilisation coefficient & 2.7 & & 2.3 & & 2.1 & & 0.9 \\
\hline & $\begin{array}{l}\text { Total urea-N excreted } \\
\text { mgN. } \mathrm{kg}^{-1} \cdot \mathrm{d}^{-1}\end{array}$ & $25.9 \pm 1.1$ & $b$ & $17.0 \pm 1.0$ & a & $34.5 \pm 1.1$ & c & \\
\hline
\end{tabular}

centration on most parameters was analysed by oneway ANOVA $(p<0.05)$ and Tukey multirange test (variance homogeneity). When this was not possible, the non-parametric Kruskall-Wallis test $(p<0.05)$ was used and followed, when necessary by Student-Newmann-Keul's multirange test. From the statistical analysis of growth results, the lowest-observable-effect concentration (LOEC), the lowest concentration of UIA-N at which an effect on weight gain is observed, was estimated.

\section{RESULTS}

All environmental conditions were stable and suboptimal over the two experiments (Table 1). Water $\mathrm{pH}$ range was 7.88-7.99 depending on ambient ammonia concentrations; in water inflow extreme values were 8.02-8.18. The coefficient of variation of UIA-N ranged from 16 to $12 \%$ in ammonia-exposed groups. The UIA-N to TAN ratio averaged $2.6 \%$ in controls compared to $3-3.3 \%$ in ammonia-exposed groups. Over the two experiments, the lowest oxygen levels were observed in controls; they averaged $74 \%$ saturation (pre-feeding levels).

In group A (73 g) as in group B (53 g), survival was maximum up to $0.33-0.34 \mathrm{mg} . \mathrm{l}^{-1}$ UIA-N after a 84 -day exposure (Fig. 1). Turbot could not survive a long time over $0.70 \mathrm{mg}^{-1} \mathrm{l}^{-1}$ : first mortalities occurred by day 35-40 and $50 \%$ mortalities were observed on day 52 and 77 in group A and B respectively.

Marked effects on weight gain related to ambient UIA-N were observed (Fig. 2). Growth was stopped over 0.73 mg. $\mathrm{l}^{-1}$ UIA-N in group A and B. Group B $(53 \mathrm{~g})$ was less sensitive to ammonia: 84-day noobservable effect concentration (NOEC) and lowest- observable effect concentration (LOEC) were 0.14 and $0.33 \mathrm{mg} .1^{-1}$ UIA-N respectively. In group A $(73 \mathrm{~g})$, a significant growth retardation was observed from day 28 at $0.34 \mathrm{mg} . \mathrm{I}^{-1}$ UIA-N and 29 days later at $0.17 \mathrm{mg} . \mathrm{I}^{-1}$ UIA-N (LOEC). No growth differences were observed between 0.14 and $0.33 \mathrm{mg} . \mathrm{l}^{-1}$ UIA-N from the onset to the end of the experiment in group $B$ and from day 57 in group A. In the 2 groups, the relative growth retardation increased as exposure duration increased.

Although specific growth rate (SGR) changes versus ambient UIA-N could not be analysed statistically (no replicate), they had not the same pattern in the two groups. In group B, SGR was not dependent on ambient UIA-N up to $0.33 \mathrm{mg} \cdot \mathrm{l}^{-1}$ UIA-N while in group A it was related to ammonia from the lowest concentration tested. The estimated 28-day and 57-day EC50 (concentration that gave $50 \%$ of SGR of controls) were $0.65-0.75$ respectively in group $\mathrm{B}$ compared to $0.50-0.60 \mathrm{mg} . \mathrm{l}^{-1}$ UIA-N in group A. SGR was $17 \%$ lower in group $\mathrm{B}$ than in group $\mathrm{A}$.

In fish fed to satiation, marked differences in food intake ( $F I)$ changes related to ammonia levels were observed between the two groups (Fig. 2c). Throughout the duration of the experiment, the fish appetite was more depressed in group A than in group B. The first week (acclimation period), FI was $24 \%$ of controls in group A compared to $42 \%$ in group B which could recover a normal appetite for a transient period (day 7-35). In the controls too, for unclear reasons, FI was $25 \%$ lower in group B than in group A. SGR was positively related to FI as reported for the first month of ammonia exposure (Fig. 2e).

Food conversion was good in controls (0.8-0.6) and negatively correlated to ambient ammonia concentra- 

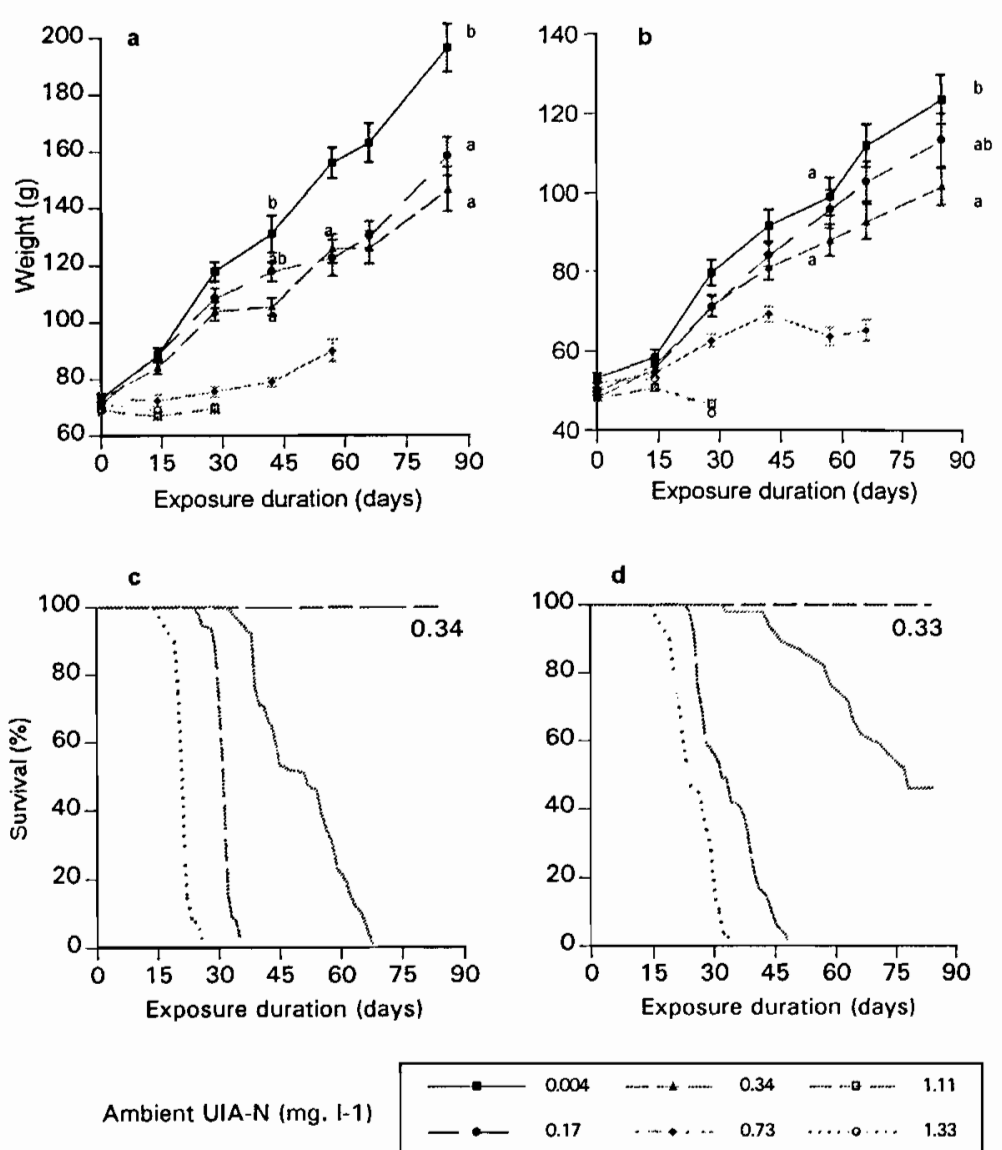

Figure 1. - Weight gain (a, b) and percent survival (c, d) versus ambient un-ionized ammonia (UIA-N) concentration in group A (73 g) and B (53 g). For clarity, statistical results are exclusively reported for 3 concentrations in the upper graphs.

tion. In the two groups, a relative $30 \%$ increase was observed when exposed to $0.33 \mathrm{mg} . \mathrm{l}^{-1}$ UIA-N; above this, the increase reached 250 to $290 \%$. Food efficiency was also negatively correlated to ambient ammonia concentration as evidenced by protein utilisation coefficient (PUC) and protein efficiency ratio (PER) values (Table 2). There were some changes in fish body composition related to ammonia concentration (Table 3 ). In comparison with controls, body crude fat content was significantly decreased $(50 \%)$ above $0.73 \mathrm{mg} \cdot 1^{-1}$ UIA-N and water content was increased in all ammonia-exposed fish (no differences related to ambient concentration). Crude protein content was stable whatever ambient concentrations were and, as expected, in the controls, no changes in the fish body composition were observed over the 3-month experiment.

In fish fed to $80 \%$ of satiation, the average total daily urea- $\mathrm{N}$ excretion rate was $26 \mathrm{mg} \cdot \mathrm{kg}^{-1}$ in controls. It was $30 \%$ higher in $0.33 \mathrm{mg} . \mathrm{l}^{-1}$-exposed fish. When expressed in terms of $\mathrm{N}$ ingested, no differences in total urea- $N$ excretion rate were observed between the controls and $0.15 \mathrm{mg} . \mathrm{l}^{-1}$ while it was twice higher at $0.33 \mathrm{mg} . \mathrm{l}^{-1}$ UIA-N. In 7-day-starved turbot, endogenous daily urea- $\mathrm{N}$ excretion rate was also significantly increased ( $77 \%$ higher) in the $0.34 \mathrm{mg} . \mathrm{l}^{-1}$ condition compared to the controls and $0.14-0.17 \mathrm{mg} . \mathrm{l}^{-1}$ UIA-N conditions (not significantly different).

\section{DISCUSSION}

This study has contributed to the establishment of "safe" and "acceptable" levels of ammonia for the long-term growth of 53-73 g turbot juveniles when exposed to usual or abnormally high constant ambient concentrations. All other environmental factors were stable and sub-optimal over the 84-day experiments.

In turbot juveniles, survival may be maximum up to $0.34 \mathrm{mg} . \mathrm{l}^{-1}$ UIA-N (11.5 mg. $\mathrm{l}^{-1}$ TAN under the experimental conditions used). They may survive in ammonia concentrations as high as $0.70 \mathrm{mg} \cdot \mathrm{l}^{-1}$ UIA-N (20 mg.1 $\mathrm{l}^{-1}$ TAN) without any mortalities for one month maximum. This chronic toxicity level was about $27 \%$ the average 96-h LC50 in turbot juveniles (Person-Le Ruyet et al., 1995). It is an unusual concentration in 

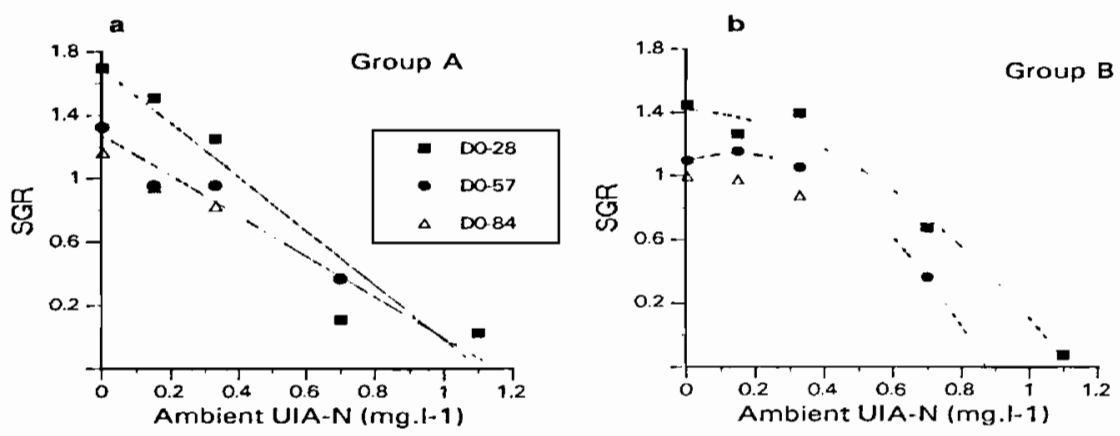

c

d
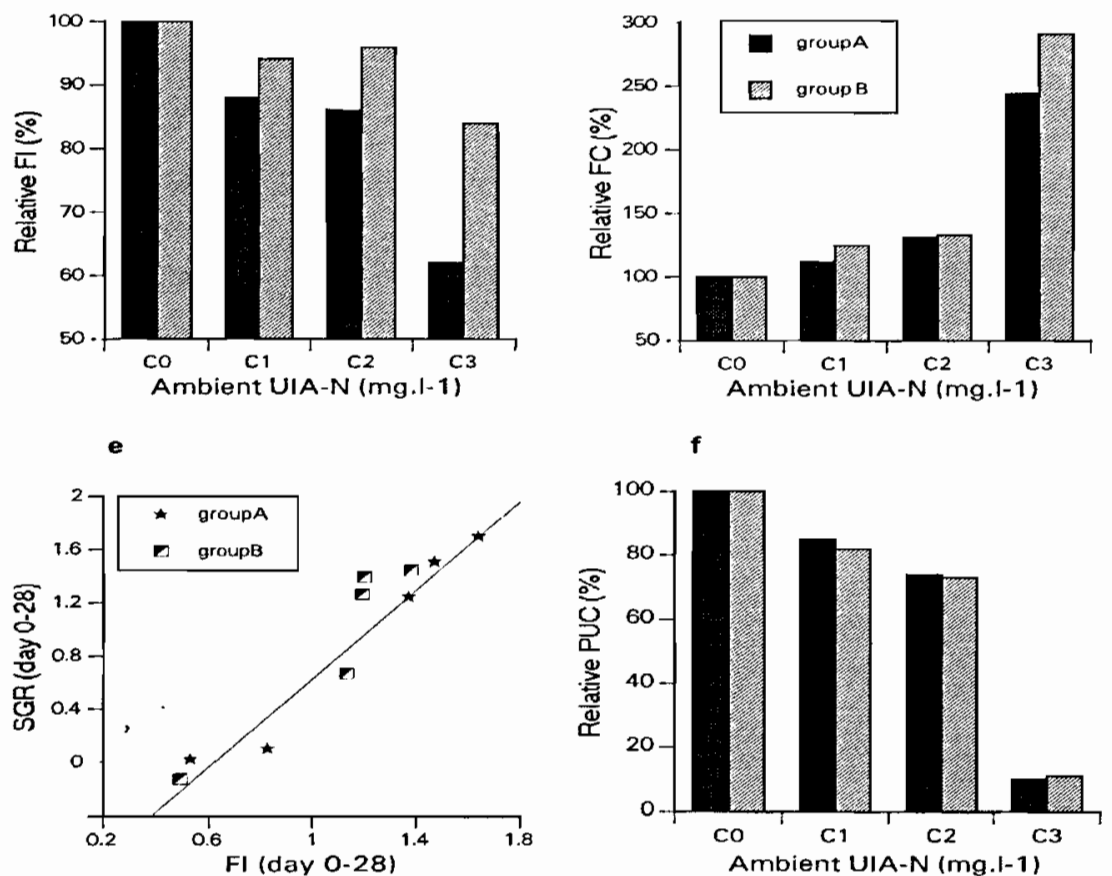

Figure 2. - Specific growth rate (SGR) for three exposure durations (a, b), and (c) relative food intake (FI), (d) food conversion ratio (IFC) and (f) protein utilisation coefficient (PUC) versus ambient UIA-N, plus SGR from day 0 to day 28 versus FI (c) in group A (73 g) and B (53 g).

intensive marine fish farming (Handy and Poxton 1993; D. Coves, personal communication, 1996). The 28-day LC50s, 1.1-1.3 mg. I $^{-1}$ UIA-N, were in the same range of values previously obtained in 13-104 g turbot exposed to ammonia for one month (Person-Le Ruyet et al., 1997). Progressive changes in turbot colour (darkened skin) and behaviour (incresased gill ventilation and swimming activity) indicated a low poisoning action of ammonia.

The growth potential of turbot juveniles may be affected under normal ammonia concentrations in intensive farming. Growth was immediately or rapidly stopped above $0.7 \mathrm{mg} .1^{-1}$ UIA-N (chronic threshold for survival). In the most tolerant group, 84-day lowestobservable effect concentration (LOEC) was 4 times lower (0.17-0.34 mg. $\mathrm{l}^{-1}$ ) and growth was not depressed up to 0.17 mg. $1^{-1}$ UIA-N, 84-day no-observable effect concentration (NOEC). Differences in sensitivity between the two groups could not be explained by dif- ferences in stocking densities or oxygen levels (better in the most sensitive group). Stocking density was low for turbot, maximum $10 \mathrm{~kg} \cdot \mathrm{m}^{-2}$, and growth rate was not affected by any change with time in stocking density (Person-Le Ruyet, 1993). The oxygen supply was not limiting, over $75 \%$ of the saturation, as in turbot oxygen threshold for growth is below $50 \%$ of the saturation (C. Pichavant, personal communication, 1997). They may be related to differences in the growth rate of the two class-size, the lower mode had the lowest specilic growth rate (SGR) before and during the experiment. Chronic toxicity thresholds obtained in this study for 28-day exposure were in the range of values evidenced in 14-104 g turbot (Person-Le Ruyet et al., 1997) as in $0.3 \mathrm{~g}$ seabream (Wajsbrot et al., 1993) and $3 \mathrm{~g}$ seabass (Lemarié et al., 1996). They were significantly higher than LOEC reported by Rasmussen and Korsgaard 1996 in $20 \mathrm{~g}$ turbot (20-day LOEC 
Table 3. - Initial and final body composition (\% of body wcight) of turbot (group A) acclimated to different ambient ammonia concentrations for 84 days cxcept in $1.11 \mathrm{mg} \cdot 1^{-1}$ UIA-N (57 days).

Means are given with standard errors and $\mathrm{n}$ (in brackets). Superscript letters indicate intergroup statistical differences between ambient UIA-N (oneway ANOVA and Tukey multirange analysis). Means not sharing a common letter are significantly different $(p<0.05)$.

\begin{tabular}{|c|c|c|c|c|c|c|c|c|}
\hline$\frac{\text { Age (day) }}{0}$ & \multicolumn{2}{|c|}{ UIA-N (mg/l) } & \multicolumn{2}{|l|}{ Water $(\%)$} & $\frac{\text { Protein }(\%)}{14.6 \pm 0.5}$ & \multicolumn{2}{|l|}{ Fat $(\%)$} & $\frac{\operatorname{Ash}(\%)}{3.6 \pm 0.2}$ \\
\hline 84 & 0.17 & (3) & $77.4 \pm 0.1$ & a & $15.3 \pm 0.2$ & $3.3 \pm 0.2$ & $\mathrm{c}$ & $3.7 \pm 0.2$ \\
\hline & 0.34 & (3) & $78.4 \pm 0.5$ & $\mathrm{bc}$ & $15.0 \pm 0.5$ & $2.9 \pm 0.3$ & $b c$ & $3.8 \pm 0.2$ \\
\hline & 1.11 & (2) & $80.9 \pm 2.3$ & $\mathrm{c}$ & $13.8 \pm 1.6$ & $1.7 \pm 0.6$ & $\mathbf{a}$ & $3.6 \pm 0.3$ \\
\hline & & & $80.6 \pm 0.7$ & c & $13.6 \pm 1.1$ & $1.9 \pm 0.2$ & a & $3.6 \pm 0.2$ \\
\hline
\end{tabular}

averaged $0.11 \mathrm{mg} .1^{-1}$ UIA-N); that may be partly explained by differences in experimental conditions, growth performances and/or variability in sensitivity related to fish origin. Long-term sensitivity to ammonia of turbot juveniles is lower than in most salmonids, but it is at the same level as in Atlantic salmon (Salmo salar) postsmolts and in Channel catfish (Ictalurus punctatus), (Colt and Tchobanoglous 1978; Russo and Thurston, 1991; Fivestalt et al., 1995). This study also showed that chronic toxicity thresholds decreased as the experiment duration increased indicating that 28-day exposure, which is recommended as a minimum in routine toxicity test on fish growth for any pollutant (Kooijman and Bedaux, 1996), led to overestimate long-term sensitivity to ammonia and subsequent effects on reproduction capacity. As discussed in Hoeskstra and Van Ewick (1993), from a statistical point of view, analysis of growth results are less standardized than survival data and, better parameters than NOECs and LOECs should be used.

Ambient ammonia concentrations may also have marked effects on feeding rate and food efficiency. There was no apparent social effect in feeding and fish size dispersion. Differences in Specific Growth Rate (SGR) to ammonia concentration pattern observed between the two groups for the lowest concentrations, were mainly due to changes in food intake; in group A, past the 7-day acclimation period, the regulation of appetite was not so efficient as in group B. Major change in food utilisation efficiency was only observed at high ambient ammonia concentrations. The relative increase in food conversion ratio and the concomitant decrease in turbot capacity to utilise efficiently ingested protein were acceptable up to $0.33 \mathrm{mg} .1^{-1}$. No major changes in body fat deposition occurred as long as growth was not inhibited. Conversely, body water content was significantly increased in all ammoniaexposed turbot. This water content increase may be related to exposure duration; previously it was only observed at $0.8-0.9 \mathrm{mg} . \mathrm{l}^{-1}$ UIA-N in 34-42 dayexposed turbot which looked swollen before death occurred (Person-Le Ruyet et al., 1997). In turbot juveniles exposed to ammonia, threshold level for food

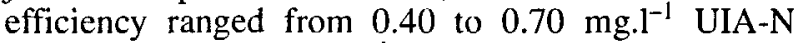
(Rasmussen and Korsgaard 1996; Person-Le Ruyet et al., 1997, this study). Data from this study are in agreement with general findings that in any fish species fed to satiation, food utilisation efficiency is severely reduced over environmental conditions inhibiting growth (Jobling, 1994). In no-ammonia exposed turbot, all food parameters values were within their normal range (Burel et al., 1996; Person-Le Ruyet et al., 1997).

On the other hand, a significant increase in endogenous daily urea- $\mathrm{N}$ excretion rate which was evident at the highest ammonia concentration tested, suggested that urea excretion may be used to detoxify ammonia accumulated in turbot. In previous work (Person-Le Ruyet et al., 1997), under similar experimental conditions, except experiment duration (28 days), marked changes in urea- $\mathrm{N}$ excretion were observed from a higher ambient ammonia concentration, $0.80 \mathrm{mg} . \mathrm{l}^{-1}$ UIA-N compared to 0.33 in this study; longer duration of exposure may have decreased this adaptation threshold. The capability of teleosts to adapt to extreme physiological conditions that limit ammonia excretion (high ambient ammonia or $\mathrm{pH}$, air exposure) in using urea excretion as the main form of nitrogenous excretion has been described in many species (Mommsen et Walsh, 1992; Saha et al., 1993). In goldfish (Carassius auratus), acute exposure to high ambient ammonia leads to a 4-5 fold increase in urea synthesis and excretion while in rainbow trout (Oncorhynchus mykiss), Gulf toadfish (Opsanus beta) or tilapia (Oreochromis niloticus), the elevation in urea excretion is of marginal significance (Olson and Fromm, 1971; Walsh et al., 1990). Turbot may use this excretion pathway because it is a species with a relatively high urea excretion rate under usual ambient ammonia concentration (Dosdat et al., 1996).

To conclude, under optimal environmental conditions (ambient $\mathrm{pH}$ steady and no oxygen depletion) long-term exposure of turbot even to usual constant ambient ammonia concentrations in intensive fish farming affects their growth capacity. Ammonia presence at steady or fluctuating concentrations may decrease their tolerance to other limiting factors (oxygen depletion, $\mathrm{pH}$ decrease) and their disease resistance. The magnitude of direct or indirect effects of ammonia on growth may be partly explained by the instantaneous ammonia uptake from water and the metabolic cost of acclimation which could be estimated from physiological indicators values. Further studies are also required to determine the adaptative physiological mechanisms involved in short-term as in long-term ammonia toxicity. 


\section{Acknowledgements}

The authors would like to thank G. Bocuf for helpful advice, P. J. Hatt for critical suggestions regarding the manuscript, and Eileen Lane for reviewing the English. This study was supported by a special Ifremer grant: Programme de Recherche "Régulation de la croissance chez les poissons".

\section{REFERENCES}

Alderson R. 1979. The effect of ammonia on the growth of juvenile Iover sole, Solea solea (I..) and turbot, Scophthalmus maximus (I..). Aquaculture 17, 291 -309.

AOAC (Association of Official Analytical Chemists) 1984. Official methods of analysis of the Association of Official Analytical Chemists, S. Williams ed. Association of Official Analytical Chemists, Arlington, V.A., 1141 p.

Burel C., J. Person-Le Ruyet, I: Gaumet, A. L.e Roux, A. Sévère, G. Boeuf 1996. Effects of temperature on growth and metabolism in juvenile turbot. J. Fish Biol. 49, 678-692.

Colt J., G. Tchobanoglous 1978. Chronic exposure of channel catlish, Ictalurus punctatus, to ammonia: effects on growth and survival. Aquaculture 15, 353-372.

Dosdat A., F. Gaumet, H. Chartois 1994. Marine aquaculture effluent monitoring: methodological approach to the evaluation of nitrogen and phosphorus excretion by fish. Aquac: Eng. 14, 59-84.

Dosdat A., F. Servais, R. Métailler, C. Huclvan, E. Desbruyères 1996. Comparison of nitrogenous losses in five teleost fish species. Aquaculture 141, 107-127.

Fivelstad S., J. Schwarz, H. Stromsnes 1995. Sublethal effects and safe levels ol ammonia in seawater for Atlantic Salmon postsmolts (Salmo salar L.). Aquac: Eng. 14, 271-280.

Guillaume J., M.F. Coustans, R. Métailler, J. Person-Le Ruyet, J. Robin 1991. Flatfish, turbot, sole and plaice. In: Handbook of nutritient requirements of finfish. Wilson ed. CRC Press Publication, Boston, 77-182.

Handy R.D., M.G Poxton 1993. Nitrogen pollution in mariculture: toxicity and excretion of nitrogenous compounds by marine lish. Rev. Fish Biol. Fish. 3, 205-241.

Hockstra J.A., P.H. van Ewijk 1993. The bounded effect concentration as an alternative to the NOEC. $I n$ : The science of the total environment, suppl. Elsevier Science Publishers B.V., Amsterdam, 705-711.

Jobling M. 1994. Ingestion, absorption and digestion. In: Fish Bioenergetics. M. Jobling ed. Chapman and Hall, London, 99-119.

Johansson O., W. Wedborg 1980. The ammonia-ammonium equilibrium in seawater at temperature between 5 and $25^{\circ} \mathrm{C}$. J. Solut. Chem. 91, 37-44.

Kooijman S.A.L.M., J.J.M. Bedaux 1996. Analysis of toxicity tests on fish growth. Wat. Res. 30, 1633-1644.

Knoph M., K. Thorud 1996. Toxicity of ammonia to Atlantic salmon (Salmo salar L..) in seawater - Effects on plasma osmolarity, ion, ammonia, urea and glucose levels and haematologic parameters. Comp. Biochem. Physiol. 113, 375-381.

Lemarié G., D. Coves, G. Dutto, E. Gasset, J. Person-Le Ruyet 1996. Chronic toxicity of ammonia for european scabass (Dicentrarchus labrax) juveniles. In: Applied environmental physiology of fishes Symp. Proc. C. Swanson, P. Young, D. MacKinlay eds. Int. Congress on the biology of fishes, San Francisco State University, July 1418, 1996. American fisheries society, Bethesda, 65-76.

Mayes, A. M., H.C. Alexander, D.L. Hopkins 1986. Acute and chronic toxicity of ammonia to freshwater fish: a sitespecific study. Environ. Toxicol. Chem. 5, 437-442.

Mommsen T.P., P.J. Walsh 1992. Biochemical and environmental perspectives on nitrogen metabolism in fishes. Experientia 48, 583-593.

Olson K.R., P.O Fromm 1971. Excretion of urea by two teleosts exposed to different concentrations of ambient ammonia. Comp. Biochem. Physiol. 40A, 999-1007.

Person-Le Ruyet J. 1993. L'élevage du turbot en Europe. Piscic. Fr. 112, 5-22.

Person-I.e Ruyet J., H. Chartois, L. Quéméner 1995. Comparative acute ammonia toxicity in marine fish and plasma ammonia response. Aquaculture 136, 181-194.

Person-Le Ruyet J., R. Galland, A. Le Roux, H. Chartois 1997. Chronic ammonia toxicity in juvenile turbot (Scophthalmus maximus). Aquaculture 154, 155-171.

Person-Le Ruyet J., G. Boeul, J. Zambonino Infante, S. Helgason, A. Le Roux in press. Short-term physiological changes in turbot and seabream juveniles exposed to exogenous ammonia. Comp. Biochem. Physiol. (in press).

Rasmussen R.S., B. Korsgaard 1996. The effect of external ammonia on growth and food utilization of juvenile turbot (Scophthalmus maximus L.). J. Exp. Mar. Biol. Ecol. 205, 35-48.

Russo R.C., R.V. Thurston 1991. Toxicity of ammonia, nitrite and nitrate to fishes. Aquaculture and water quality. In: Advances in world aquaculture. E. Brune, J.R. Tomasso eds. WAS Publ. 3, 58-89.

Saha T.K., M.B. Arya, A.B. Dast 1994. Atlerations in the patterns of nitrogenous excretion in a freshwater air breathing teleost, Channa punctatus (Bloch), during ammonia-stress. Ind. J. Exp. Biol. 32, 196-199.

Tomasso J.R. 1994. Toxicity of nitrogenous wastes to aquaculture animals. Rev. Fish. Sci. 2, 291-314.

Wajsbrot N., A. Gasith, A. Diamant, D.M. Popper 1991. Acute toxicity of ammonia to juvenile gilthead seabream Sparus aurata under reduced oxygen levels. Aquaculture 92, 277-288.

Wajsbrot N., A. Gasith, A. Diamant, D.M. Popper 1993. Chronic toxicity of ammonia to juvenile gilthead seabream Sparus aurata and related histophatological effects. J. Fi.sh Biol. 43, 321-328.

Walsh P.J., E. Danulat, T.P. Mommsen 1990. Variation in urea excretion in the Gulf toadfish, Opsanus beta. Mar. Biol. 106, 323-328.

Wood C.M. 1993. Ammonia and urea metabolism and excretion. In: The Physiology of Fishes. D.H. Evans ed. CRC Press, Boca Raton, 379-425. 